\title{
Effects of fire and extreme drought events on forest integrity in the Xingu Indigenous Lands
}

\author{
Robson Santana de Oliveira ${ }^{1 *}$, Divino Vicente Silvério ${ }^{2}$, Leandro Maracahipes dos Santos ${ }^{2}$, Fábio Garcia \\ Moreira $^{3}$, Márcia Nunes Macedo ${ }^{4}$
}

\author{
${ }^{1}$ Programa de Pós-Graduação em Ecologia e Conservação, Universidade do Estado de Mato Grosso \\ (UNEMAT), Nova Xavantina, Brazil. *E-mail para contato: roby87gyn@gmail.com \\ ${ }^{2}$ Instituto de Pesquisa Ambiental da Amazônia (IPAM), Canarana, Brazil \\ ${ }^{3}$ Instituto Socioambiental (ISA), Canarana, Brazil \\ ${ }^{4}$ Woods Hole Research Centert (WHRC), Falmouth, EUA
}

\begin{abstract}
In the Amazon, large areas of forest in protected areas have become degraded over time, yet the drivers of these changes remain largely unknown. Specifically, we still know little about the relative contribution of anthropogenic and natural degradation pressures, such as the occurrence of fire and drought events on this process. To evaluate the effects of these factors on the integrity of forests in the Xingu Indigenous Territories (TIX), we quantified forest cover loss over the last 17 years (20012017). Using a generalized linear model (GLM), we evaluated the role of six different predictors: type of forest (upland or floodplain); number of times the area burned; population density; distance from villages; distance from major rivers; and the number of extreme drought events. Results showed that the area with forest structure in TIX droppedd $9.3 \%$ from 2001 to 2017 , and half of this change occuring after 2015. All variables were important in explaining recent forest loss, but the number of times the area was burned, the number of extreme drought events and the type of forest were the main predictors. After three fire events, the likelihood of forest loss in a flooded area (70\%) is $30 \%$ higher compared to an upland area (40\%). Given the same number of fire events, areas that have not suffered with extreme droughts showed a 25\% lower likelihood compared to areas with three drought events. Our results indicate that the forest type and population density in protected areas are important in explaining forest loss in indigenous lands, but changes in fire regime and the occurrence of extreme drought events are the main vectors of recent changes in forest cover.
\end{abstract}

Keywords: forest cover, fire, drought, upland forest, flooded forest. 